TITLE: TIME-RESOLVED X-RAY DIAGNOSTICS

AUTHOR(S): P. B. Lyons, P-14

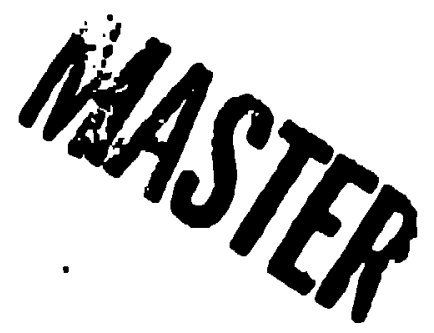

SUBMITTED TO: Low Energy $x$-Ray Cor.enrence

Montorey, Califormia

June 198].

先

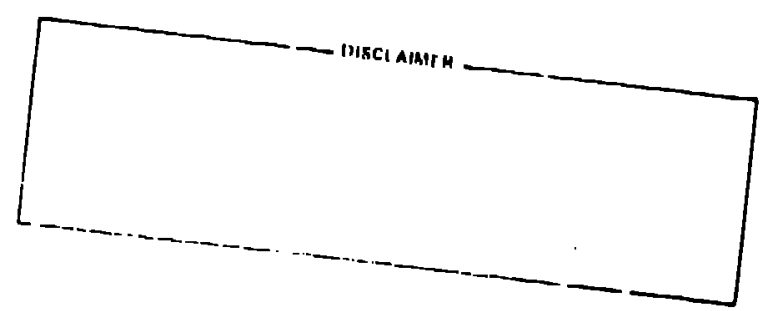

By acenptence of this article, the publisher recognictet that the U.S. Govornmmnt rotuns e nonexclisive, royeliy frun licanso to bublish or poprucluce tha flublushed form of this contribu. lion, or 10 allow othan 10 do so, for U.S. Govermmenl liup poses.

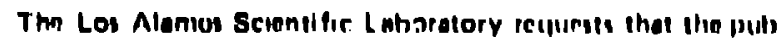

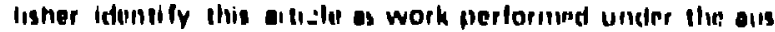
nices of the U.S Empertment of Linergy

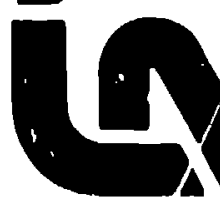




\title{
TIME-RESOLVED X-RAY DIAGNOSTICS
}

\author{
P. B. Lyons
}

Los Alamos National Laboratory, P. O. Rox 1663, mS 410, Los Alamos, NM 87545

APSTRACT

Techniques for time-resolved $x$-ray diagnostics will he reviewed with emphasis on systems utilizing $x-$ ray dlodes or scintlilators. System deslen concerns for hiph-handwidth ( 1 (iHz) diagnostics will be emphasized. The limitations of a coaxial cable system and a technique for equalizing to improve bandwidth of such a system will he reviewed. Characteristics of new mult1-GHz amplifiers will be presented. An exsmple of a complete operatlonal system on the Los Al amos Helios laser wlll be presented which hus a bandwidth near 3 GHz over $38 \pi$ of coax. The system includes the cable, an amplifier, an oscllloscope, and a difltal camera reatout.

Nanosecond and subuns time resolution of low energy $x$ rays may be achleved with at least inree types of di agnosilic systems. Photoelectric $x-r a y$ diodes $c r$ scintillators and optlcal detectors provije electrical slanals for electronlc recording and prucessina. The fliotoelectric process may also be used to provide a source or electrons for deriection in a streak tuhe.(1)

The ririt two types of clagnostic systems will the discussed in this paper. The paper is organized in sections that highlight specific sub-systems: the intector, the cable transmission system, the data ccorder. supporting instrumentation, and system considerations. Examples will he drawn rrom experlences at the Los Alamos National Lahoratory with the large C. laser systems (frimarily the Hellos syster). The fibal section reviews the parumeters of an cperational syster, at the Hellos facllity wrich is providing a ? "lin handwidth over $38 \pi$ of coax.

\section{$X$ - RAY TFTFCTOK}

X-ray phictomectelc diodes provide a very simple .... retentindly, very $r$ ah speed, detector for low mirly $x$ rays. The detector relles on $x$-rpy interaction in an $x-r$ photocathode with ouhsequent ralase if pictoclectrons. Auger electrons, and secondtry alecirons from the materlad surface.

The sensitivity of the detcetor is approximately frifortional to the $x$-ray attenuation coefriclant and der onstrates increased sensitdvity in spectral reglons (alcue $x$ ray edges) with increased attenuation. Tie dolector current is dominated ty secondary plartron: ant is thus very sungltive to surface conditlons. iurface condlions are, in turn. strongly influencel ty lie coshindques used to prepare and store the photorathice. These concerns, es wall os detalled sensitiv1iy data, are ovallable in publlahed literature, $(2-3)$

The time responsm of on $x$-roy diode is poverned ry alpile considerations. The detector geometry resembles p Iarallel ciectrode conflauration. The response in "ucl: aecmetry la simfly calculated. (4) Mie rise timr 13 elven by the time for electpons to tra erse the Hhore-cathode gap. he fall timo is Riven by the Rr ir constant. The ironaltion between the dode ond - hir transmission 1 !ne must he cerefully enplnearad to rindmizu reflections. A poor tranaltion can completely dirlnate the excellent time response resslble with an clilmazed dlode geometry. Rase and rall times helow ro

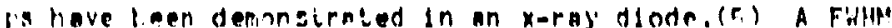
lor surh a diode helow th ps thould be achlevatle. fxintilletors ore also useful for low eneray $x-r$ by datection.(6) In selntillotor, the eneray of in.e clifent x rays da transferred to excitation of the solvent (tave pluatle) moleculea with subsequent transfer to other scintilloting molenulur apecies, the time respolls. Is dominated by the inter-malecular transer limes and the decay time of the final acintlliator molerule. Standard commeralal acintidlators provite I Ime rezponse as short as 1,3 lis(7) and aperial acintllletors provide time reaponse below pro pa with peduced light output. (B)

Thr cholce betweer: i-ray dlodes end selnt lliators depends on several foctors. The dindes will provide. raster syatem but require consideroble care in surface preparetion and protection for Acrurite measuremerts. a good vacuum, below at least 10 Torr. Is essential for operation. Gain is achleved only with electronic amplification. The scintillators are less sensitive in vacuum requlrements and care in stornge lut requlre that inc photodetector re shielded from all extranecule sources ot visitle light. Cain is caslly achieved if needed with photomuinglers (FMT). Rut the Fl'T moyte susceptible to high eneroy rackground photong in ilo same environmellt.

In FiR. 1 a sensitivity comparlson lintwen tifill flastic and a windowless $A 1 x$-rav diode is pliven. The lastic is assumed to he courlad to a plotodiode with a tyrical $5-2 C$ surface. At lower energles, the $x-r a y$ diode sensitivity is superlor. Some $x$-ray diode surfares show sensit dvity well ahove the Al Alode.'

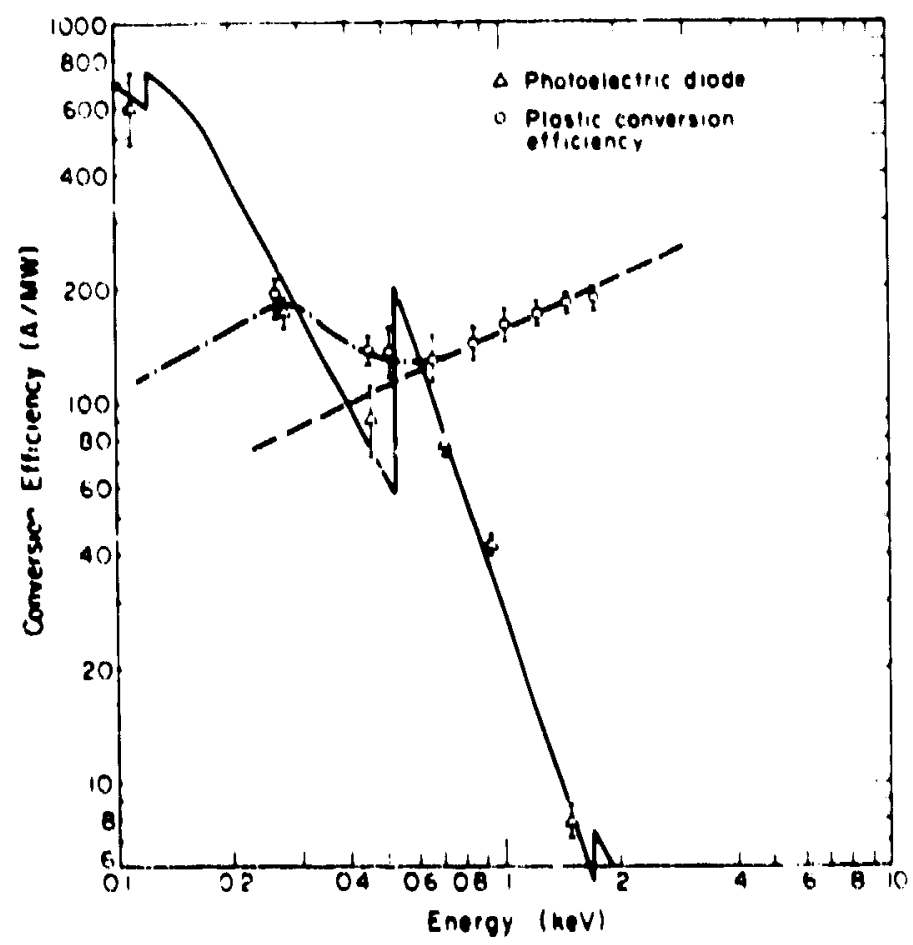

Fia. i. Comparison of rerresentitive As $x$-ray alindes

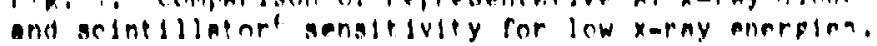

The arintlliation must he masulured with nome tyje or photonenaltive detector. Min detectar can ter " simile birlanar photollode or photomultililar (riet)

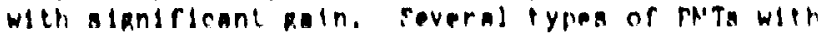
sut-na resonono are avaliahle, (o) the fastest sulteple PMTa commercially avallable ut ll te a mlerochannel plate (MCr) un the onin ntape and provide a Filne of are

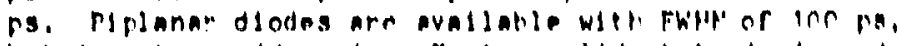
livi do not provide pain. Faster aulin atete devices do exist, but thelr vers limited detection areas are not usueldy complatille with acintillelors. When a PNT is uapd, attention must in Rluen to dimitatlons on prak 
linear charge and/or current output capability of the unit. Most PMTs have definite limits or these output values which are largely independent of PNIT gain, Operation of a PMT at high gain can restrict the dynamic range of the instrument to a very smajl value. For most applications, Bains of $10^{4}-10^{5}$ are optimum. Either scintillator or $x$-ray diode systems can frovide sensitivity in selected xuray epectral regions, The $x$ mray diodes show a rapld variation of sensitivity with $x-r a y$ energy and demonstrate significant changes in sensitivity near $x$-ray edges of the cathode material (cr Fig 1). Scintiliator sensitivity can he varjed by changing the thickness of the scintillator. therety altering the sensitivity at high energles. The system sensitivity can be rurthe" derlied through the use or:

a) $x$-ray reflectors - prividing reflection only below a critical eneray.

b) x-ray ridters - Frovding transmission as a function of tre raterial attenuation properties. Tive we of $x$-ray edges can provide acrsideratle spectral resolution.

r) x-roy ratrescers - rroviding (ddeally) sensilizaly ondy for $x$-ray enerples exceeuting tre $x$ uray edfe of tre fluorescer.

a) Frafe reflectars - providine reflection ondy when the equap cerditions are satisfled.

c) erazlrig incidence fratinos. rroviding reflection when the pratsris equations are satis? $\therefore$.

l.ow enerfy $x$.roy systens frequent ly require the ua. of very thin rolls. Euch foils can lie rolled. ercetied, or vacuum deposited defending. on the farticular material.

Mnny low-risolution systems use either a rlitared boife or a rllter-fluorescer peometry. Flpure? rro$\because$ ien atl example of rilter-fluorescer system sensilive 1 $y$ for a detection channel intended ror trmparaturas 1.' ir l keV. The system consists of a Mi rere-filter and 7 fluorescer in the di-ray boan with a ti nost-fllter

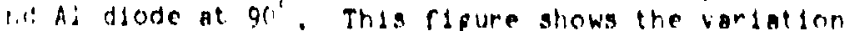
" cliannel response vs $x$-ray enerpy as additional - - arents of the channel are included. Filtere liurescer systems are much less sensiture tion lditured dlode systems. For matly applicullon: in icl is aplicistics, the rileer-detertor system la used(10) and ivlenl responses are piven in ref.

TIATA THANEYISESOOH SYSTHM:

Coaxinl calices are far from perfect transmission colly. High hondwideh slpnals surier serlous disiorIon as they profapate alonp conx rabies. The simplest alution would involve location of the recordina intruentation very close, withln a rew meters, of the intertor. In rractice, however, this is not e fensible Alternative. Sienificant radiation and electrical lackeround can be anticlpated near the tapeet aren of bily laser system and an n-theor purped laser (like the las Almos tellos laser) would he an even more difflcult enviromment. In aldition, personnel are exclixted Ircit: the corpet orea during tests and the recording cifulpment would have to to remotely controlled.

Hadiation backeround providas partleularly servere protidem with modern hipt spend oscliloscopen(11) Which utllize micro-channal plate (NCP) andn element preceding the phosphor. The Per explhite sientricant radlation sensitivity.

Theae constderations require that the recorder be located some distance from the detector. Thus coax lines, typleally $50-40$ m in length, are required, The severe IImitationa of lir cable then lecome serlous concern.

In Fin. 3 the attenuat Ioll in dli is shown as a runction of irequency ror 37 m of anered types or $h$ lah rroquency coble, tancer cab! shows slanflcantly lower loss ot odl frequencirs, but other considerationa arque ocednat. the large colide. As practlcal motier. ip. lareest oobles are extremely dicrleule to handle. A non-linear phase characteristics of several cables are shown. Thus whlle the largest cable has the least attenuation. It shows the preatest phase distortion. coax system will "ring" or oscillate at the opproxirate frequency, $f_{R}$, where the dispersive, or nonlinear.

phase shift exceeds $180^{\circ}$. In practice a system will he stabie if the rinping frequency is attenuated by $?-$ ir ob below the attenuation at the half power frequency. $r_{3 a b}$

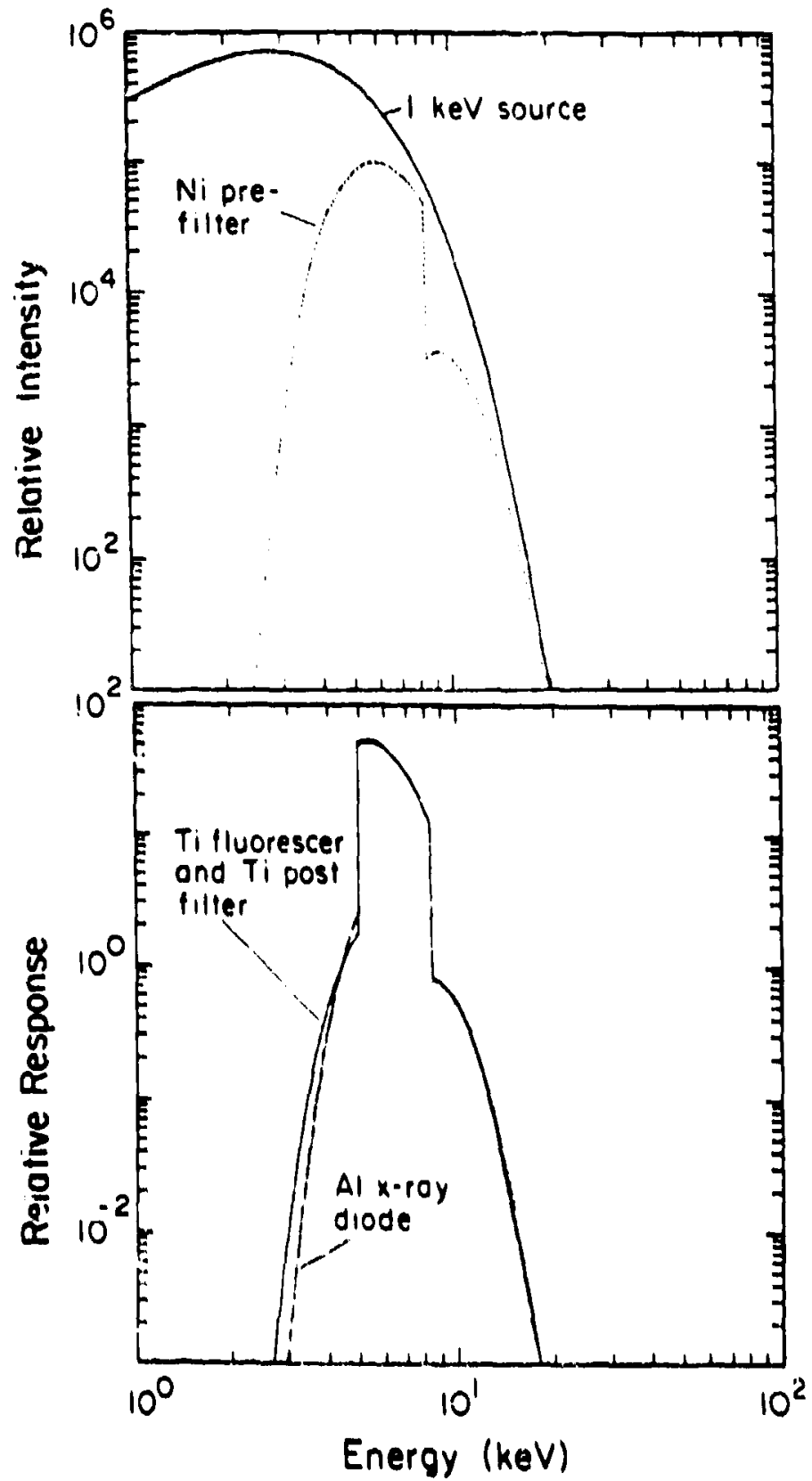

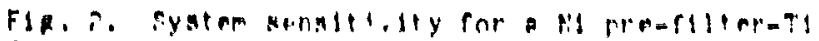

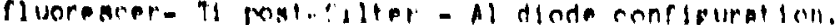
in fie. in the t arl lianek source in netenualed ly tranamiastere throuph the NI Pre-filtare. hion lia ti

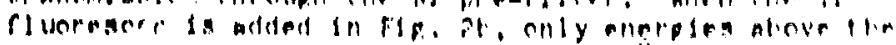

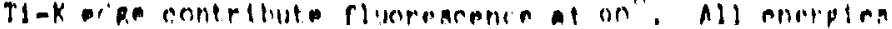

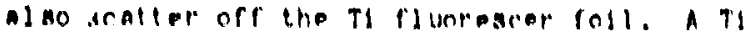

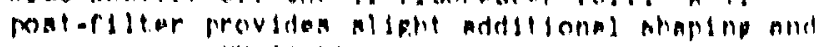

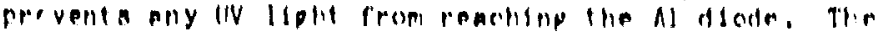
al dlode (with a lor entrance wlidow) then delecta the

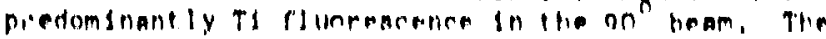

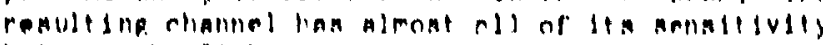

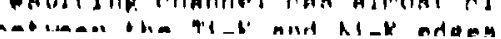


In Fig. 3, the ringing frequency, $f_{R}$, is shown for each cable. Note that the larpest cahle rings at about $2.5 \mathrm{GHz}$. The ringing frequency cer also he thought of as the approximate frequency above which modes other than TEY can fropogate. Cable ringing is shown experimentally in Fig. 5 where a short pulse was used to exalte a 15-m length of larg.s diameter cable. The cutput was measured with a sampling system.

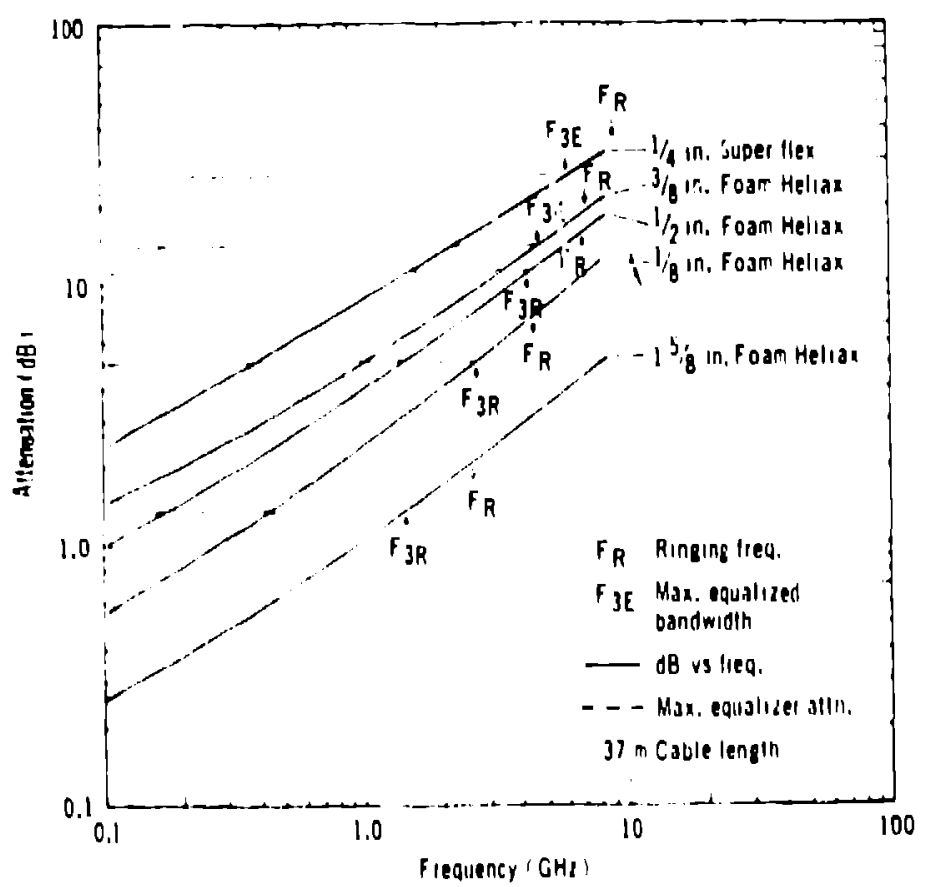

If. I. Alteruation vs. rrequency for selecten libl-irequency conxlal cables, sen taxl for disrusslun Cl rifure ablireviatlons.

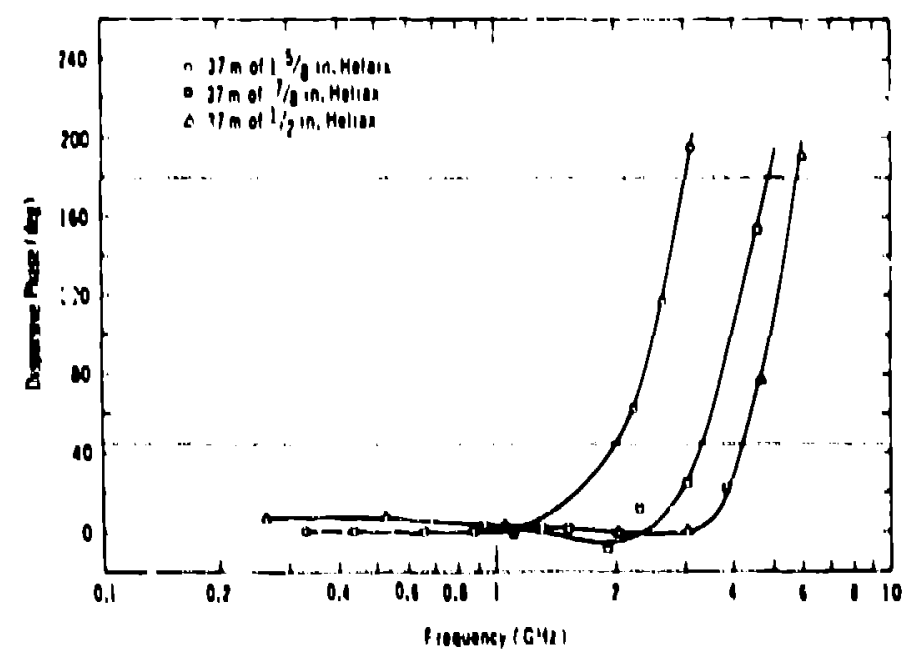

Fin. H, Non-dineme phase characterlatira for il $n$ lenktlis of several coaxint cobiles.

The bondwith of ally aystem can be Improved through equadiration. Thla technlque Involvas the Introduction into the line of a hish pasa fliter whose rrequency choroctarlatica compensate for the renuency roll-orf of the orlatnal system. The syetem sensitivity is reduced but on improved system rendwidth results. Thls is 1llustrat.ed in Fiz. fe. It is jmportent io note that equalization may he applied to ans electrical system whose rrequency charasterlstles are known. The "gystem" may he only a cable, only an oscliloscople, or a complete detector/cable/amglifiprl oscilloscope combination.

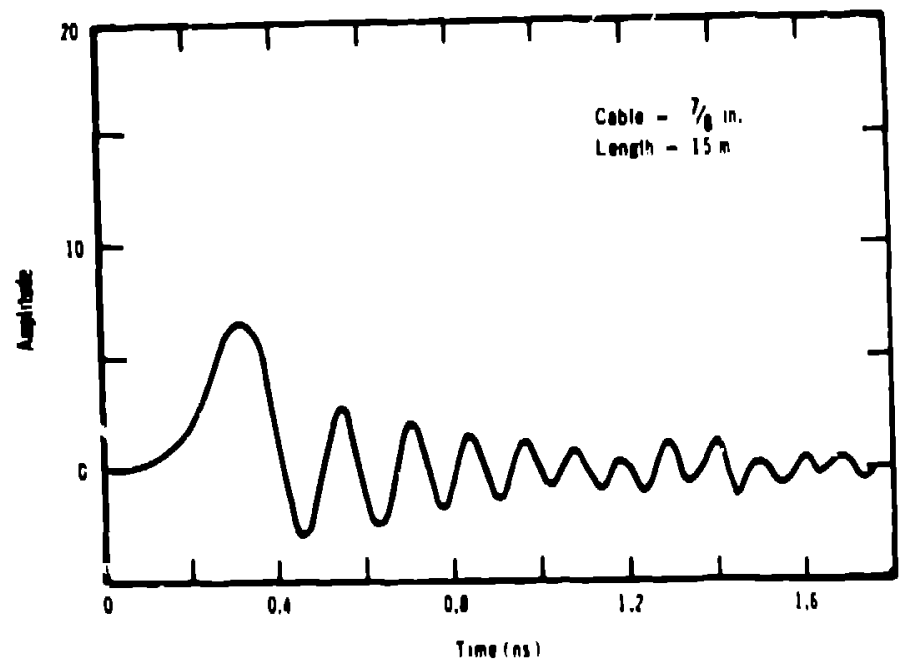

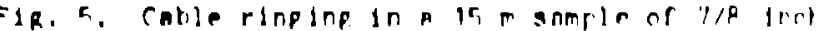
conxial catle.
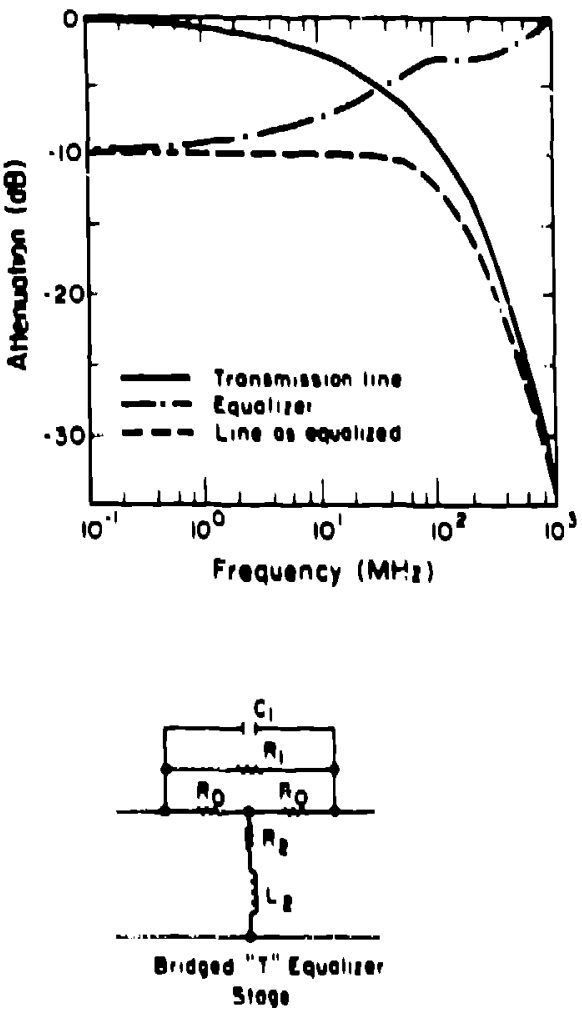

Fla. P. a) An example of phe corrept of equaldzat ler and $n$ ) one mastlile entiallzel confleuratlon.

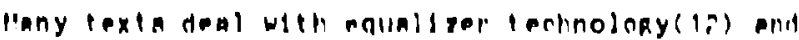

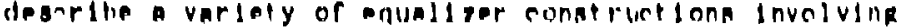

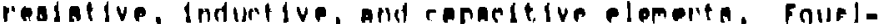
lzers may he matrbed te lle IIne charencteriation o provide "motehed" or "non-reflectlve" wauall ter of may he reflective, bille reflectlve equaligere ore 
simpler to design and fabricate, care must be exercised to assure that either 1) the coaxial cables are of sufficlent length that the reflections do not i..pair the data, or 2) that the system is sultably back-termirated to prevent mulitiple reflections. A standard type of matched equalizer, the "bridge-tee" construction, is shown in Fig. $6 \mathrm{~b}$.

The various conxial cable systems discussed earlier can be equalized. However as previously described we must assure that $f_{R}$ is attenuated well below the rinal cable $f_{3 d b}$. With this concern as a quite, the maximum equalized bandwidth for each cable is presented in Fig. 3 and labeled as $f_{3 \mathrm{db}}$.

Standard components may be used to construct equalizers with srequency characteristics providing $r_{3 d i}$ into the 500-1000 $\mathrm{MHz}$ range. However. as frequencles exceed $1 \mathrm{CHz}$, the standard discrete components have too much stray and/or distributed reactance to allow construction of computer-generated deslens. A rew type of equalizer has been originated to address this high frequencv area. (13) This equalizer consists of a micrsstris transmission line to which one or two microstrip stub lines are added. Each stub line is terminated in a resistor and the stubs may be different impedances and lengths. The reflectlons from the $v a r i o u s$ line/stub and stub/resistor interfaces can be tallored to give sultable high pass filter characteristics.

Hybrid thick rilm circult technolopy has al so been exiloreci for construction or mult:- $-\mathrm{CH}_{\mathrm{Hz}}$ equalizers (uing conventional designs like the bridge-tce of Fla. (1), but to date has not aproached the stub equalizer success. The stuh equalizers can he nullt with conventional printed circul: techniques and closely bf roach computer calculations of expected performance. To conclude this section. Fig. 7 is constructed Irep the data of FiR. 3. The ltenuation of rour cossitle coble types is shown. From Fig. 7 the ort imum calle cholce ror $37 \mathrm{~m}$ cahle dength and a speciflo inridwdatl, san be quickly determined.

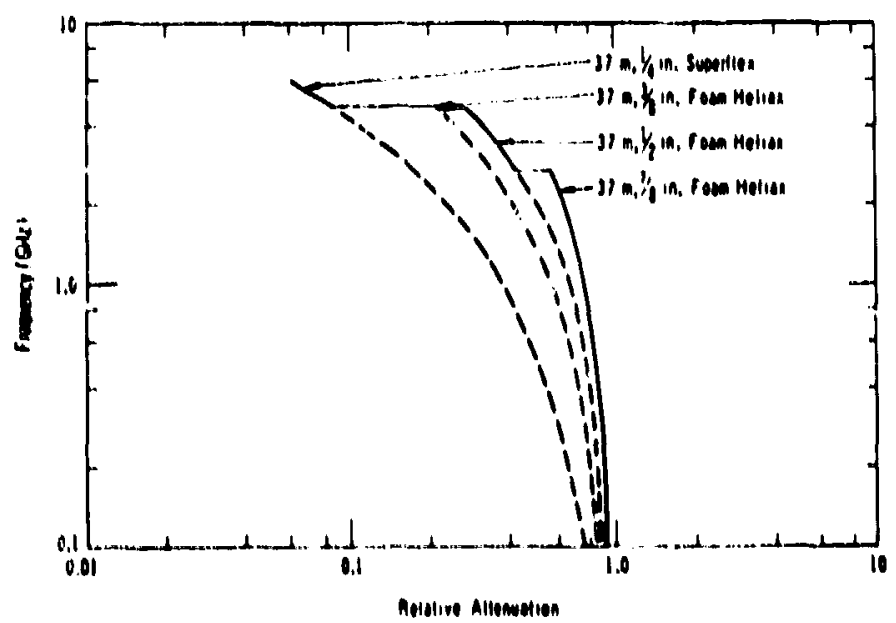

11. 7. Frequenry and atcenuation ror $37 \mathrm{~m} \mathrm{hiph}$ Irejuancy cablas withln the operatlng ranae of each cable.

\section{DATA RF, (UARER:HS}

liew optlons exlat for dota recording ahove siln Mll: bundwadth. No commercinl A/D converter or trunnient disltizer (except the 7913/direct acreas) can prusently apprench this bendwidth with ncceptable realutinn (a blte). Sumpling technlques de achlove thls handwidth

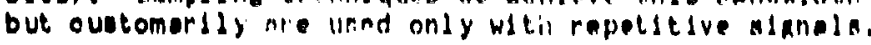

Many parameters (cost, mode of operatiun, detalled frequency response, over-voltage protection, etc.) must he addressed in selecting equipment for each application. However, as a major over-simfli flcation, several presently available recorders are compared in a twedimensional space ( $r_{3 d h}$ bandwidth vs. sensibility) in Fig. \&.

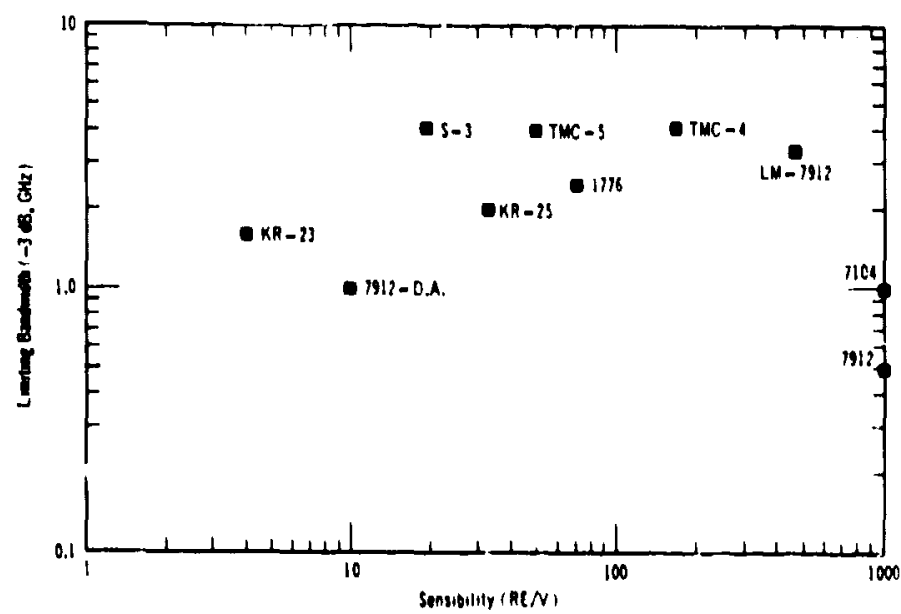

Fip. R. Pandwitth and sensirlldty rer several commerclal recorders. Spe text for detalls.

Sensibllity to defined os the number of resolitioll elements per input volt. A resolition edement as arrined elthar as a trace width ror an osclllosiropa ar a least-signiriant-bit for a dipltizer. The artual valun of sensibllity quoted for ench recoraer is oren to considerahde interpretaticin and is not ari exact quantily, (Varlous trace widths or sensitivities may he seer in different sumples of glur: recorder, me sensilillity velues in Flp. A should tie treated as rolis! Ruldes orily. The equiment descrithed in fla. i is mede by Tektronix, Tire, (7012-direet access, 701?, i1nil), by ECiRG ine. (KR-2? and KR-Pr), hy Lorkherd( 14 )

(LM-7ol:), hy Lockterd and FGs(i(15) $(5-2)$, hy " lon Al mos/Tekt rondx collahoretlon(11) (1776) and hy Thomson-CSF (TMr-H and TMr-r). The Thomson-rsf, the 1776, and the KR-?5 scoprs uan MCF current amplifichtion.

All of these recorders are elactron heam devices (conventlonal osclllouropes or acnn converters) exere the inple-shot=ampler $(S=2)$ eystam. Thla systam

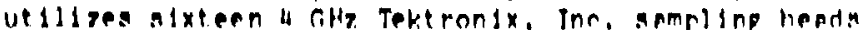
stohed and timed by a single trlerer pulse. The Inpul

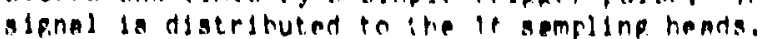
sixteen hifer rendwldle amples are ihus recorded.

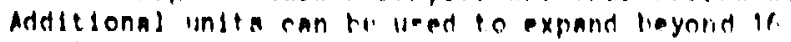
samples.

The 1776 csedlloscope is used in mocternta numptio. tIas in several los Alomos proprams. It serves a. another example of equallzation technolopy. The reamise or the ranic scope, without equallyation, in

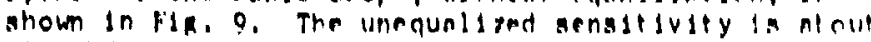

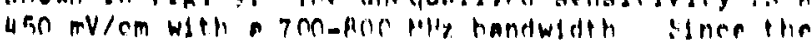
ottenuation curve ia ra! mly amooth, the lundt can lir equalized to muen hipher handwidtha. (Net ahown in FiR. O, hut of equal importance is that the phane

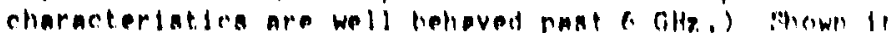

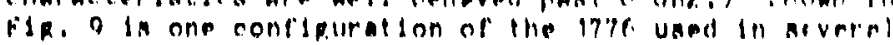

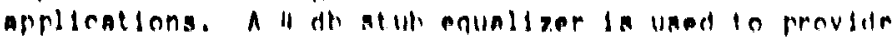

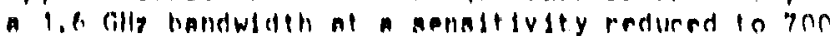
mviem. The exemple in ripure a wan enundlind to alour P.5 cillz and provided $1.1 \mathrm{~V} / \mathrm{km}$ senaltelvity. The

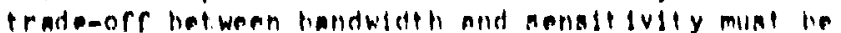
Rulled hy the specirle axpreiment. 


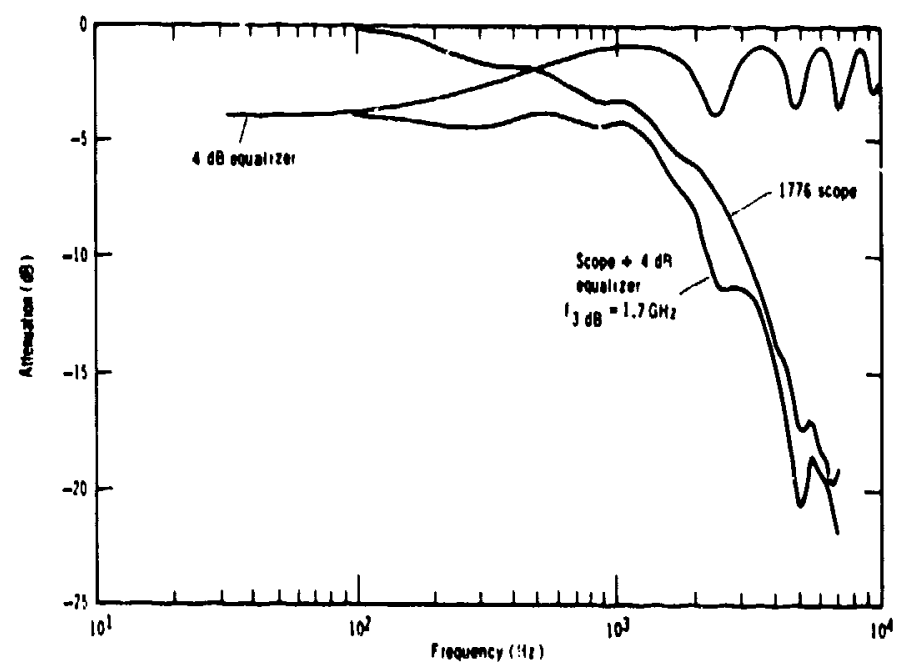

Hig. 9. Frequency response or the 1776 scope in an urcequalized mode and in one equalized $(4 \mathrm{db})$ mode. The tqualizer response is also shown.

\section{SUPPOFTING IMSTRINENTATION}

This section briefly addresses three classes of insirumentation whlch are orltical in high randwidth cysitris: amplifiers, test instruments, anci scope dipllizers.

An amflifler or sultable handwidth can lncrease the sersitility values shown ill Fip. 8. However, the ar lifler must be carefuldy tested to insure tinat it is net irtroducing significant distortion into the recorded system. Some ampliflers con introduce severe riniling or other altifucts into signals. The mplifier rust ndse have enouph linear output to deflect the hosen osc11:oscope.

Test instruments are required to rerify the pulse resionse of each component of system. Poth impulse and step gennrotors provlde sultuble data for subse quent fourler analy!z.(96) toth amplitude and phase rust be inspected in the Fourler nolyois to insure winquate pulse ridelity. Pulse generators moy use rltier step-recovery diodesii7) or mercury pulsers.( $(H)$ Ticso dlodes con deldver un $t 330 \mathrm{~V}$ at hlah repetition "htes in a 60 ps impulse whlle the mercury pulaers can provide much larkel voltakes in singla shot more. iunnel dlode pulsers(19) can plovide 20 ps rlselimes with $250 \mathrm{mV}$ outpul, Nercury puluers rabrjcoted at Los ilamos. simllar to those descrlbe in ref. 18, have

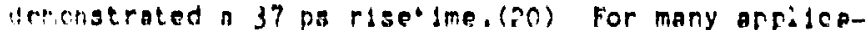
lions a set of calltirated step generatora(21) whlah irovide wall behoved and characterlzed step anapes rom if 10 ?no ps is very userul and can be ordered rrom lil:?, lelay lines ore required to irovide trianer mivance limes to the recorder aystem and doeliy would lrevide r.,0 ng deley without pulse dlstortion. Cryom crabe lines at liquid He temperatures wlth supercontuctinp couxlal cables hove been documented with 70 nu dolay ard, ro cilly bandwidti, (2) simllar lines conseructed with $3.1 \mathrm{~mm}$ diameter neml-riald coax in liquid $N$. constructed at los Alamon provide bo na delay with a landwidth of OHz, The Ios Almmos lejay line requires $p$ de equaldzotion to achleve the bandwldth.

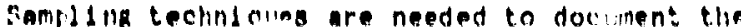
performance of sever if the componentes discunsed in

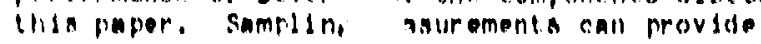
liandwd dh data up to, Gill, (?3)

The importance of teat instrimentation canrot be overemphandzed. At.tempts to rody oxelunively on manufacturer' apecificetions or llterature deseription or apecllications for almilar nyatema will usunlly be met witl serious callure. Mlah bandwith syatems penulre careful stention to ald detaldo or syatem conatruntion and test racilities are essential. Any equalization al so demands detalled knowledge of system response.

The rinal area of useful instrumentation corcerns oscilloscope digltizers. For systems using scepes. film recording may be used. An alternative would use a vidicon tube to scan the scope face. Such systems. based on SIT VIdicon tubes, are in use at los

Alamos.(24) In a rapid test schedule, the desirarility of such devices is apparent.

\section{SYSTEM CONSIDFRATIONS}

The cholce of a complete system must he gulded hy the experimental requirements. The concept of sensibility, intronuced earlier, has proven to be very useful in characterizing experimental requirements. Each experiment can be characterlzed by a handwidth and sensibility neede i to wdequately record the anticipated data. The sensiblilty is deduced from a review of the required resolution and the anticipated out nut sipnal levels.

As an example of such system considerations, graphs like Fig. 10 may he constructed to show the achievable bandwidth and senslbllity for several recorder systems operating through 18 and $37 \mathrm{~m}$ cahles. If an experiment required $3 \mathrm{GHz}$ handwidth. If 100 resolution elements $(F, F$,$) are required, and if in$ volts peak slanal are expected (requiring $10 \mathrm{RF} / \mathrm{V}$ ). then the 1776 and $\mathrm{T}^{\mathrm{M}} \mathrm{C}-4$ systems can he used with C.r inch cable.

The beam dlapnostic system for the felios and Antares laser was constructed from simllar nonslderatlons.(25) Thirty-elpht meters or 0 . Inch catle. amplification(26), a 1776 oscllloscope, and a difitel camera were used. System modeling pulded the cloler at a $3 \mathrm{GHz}_{3}$ system handwidth. Without equalization the

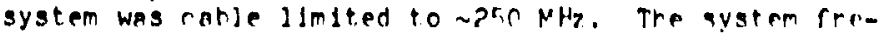
quency responce (Curve A) 1s shown in fipure il along with the calculated performence (Curup $P$ ) of a stul equalizer with ia th equalizetion and the calculated rinal system response (Curve C). A $?-3 \mathrm{GHz}$ system resulted and provided the measured resmose of Fip. $1 ;.$

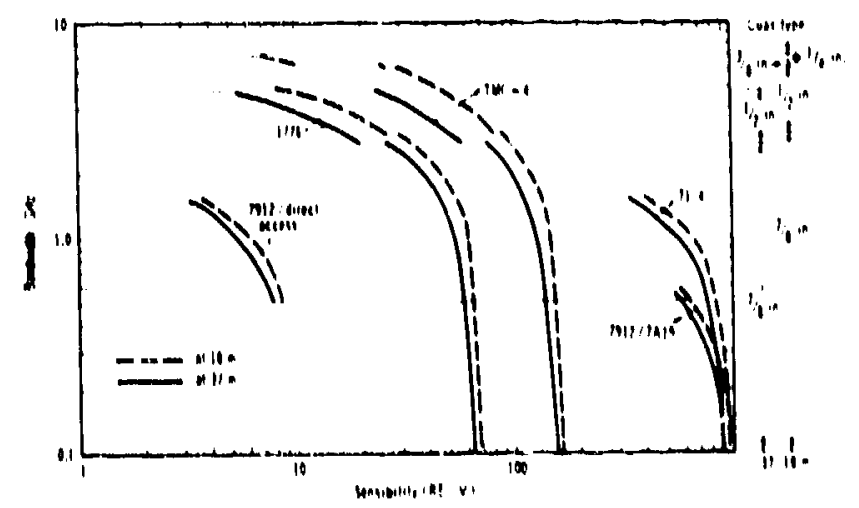

Fip. 10. Systom sensiblidty rop nyatems lased on rive

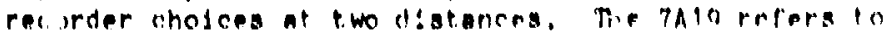
- Tektrolldx, inc. preamplifler. 


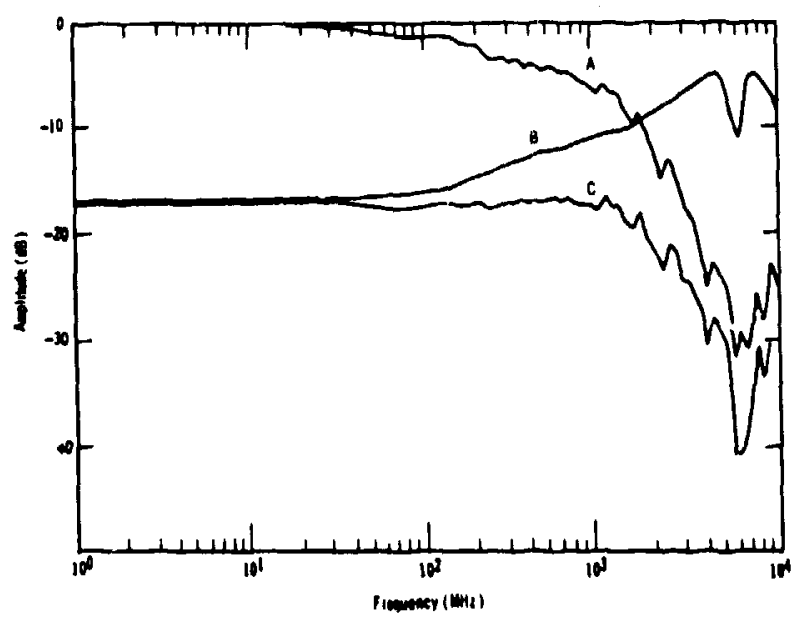

Fir. 1 1 . Neasured system rrequency response for the Helios heam diagnostic channel consisting of $38 \mathrm{~m}$ of $c .5$ inch coax, an omplifler, a 1776 oscliloscope, and a score trace digitier. Calculated equalizer response and anticlpated system response are also shown.

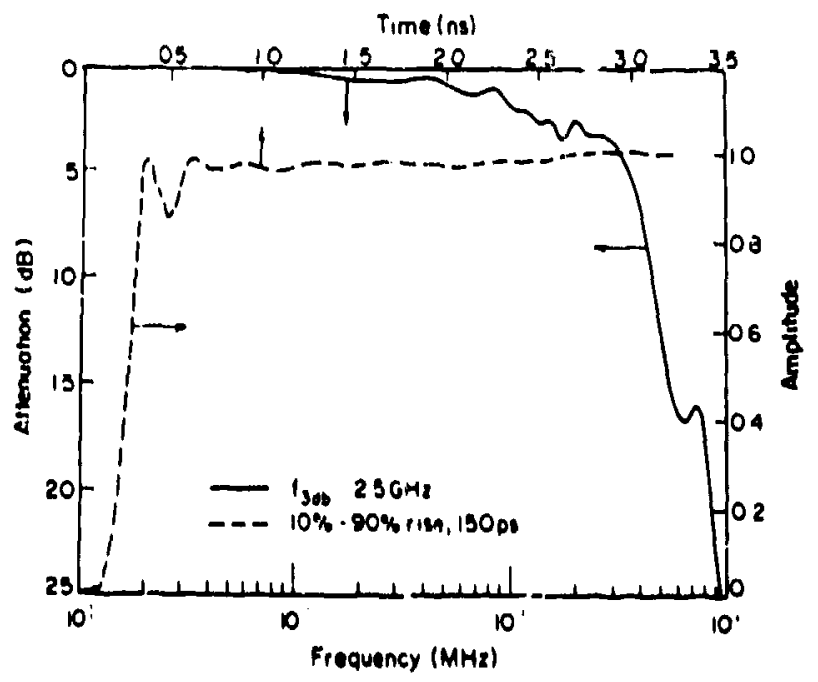

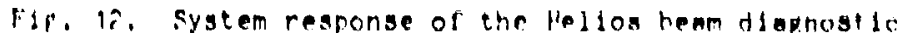
rinunel.

\section{renclileteh}

In this paper the elements of an $x$-ray detector ryatem !ave been presented. System responses over zeity way lie conatructed from the technolopy presented limrel?.

As rinal toris, the sutgret of data unroldin should he mentioned. Uncoldina, or deconvolution, may t: used to recover additional syatem bandwidth.(27) The handwldth that can he recovernd by deconvolution is hiphly depandent on hodse elther in dato or In system resionse. In several sltuationa at Los Alamos. bandwdoth has been Increased liy recovaring rrequency attenuation of about is ob, but this value depends crlticaliy on the Indivlduel nystem. Altempts at excesslve deconvolution introdure serloun nolse into the dote and can actually dearade, rather than improve, aystem perrormance.

Proper system desian is providing mul 1 -cilly racording copabildties at the Los Alamos National laborat or $v$.
The author gratefully acknowledges extensive contributions from $F$. K. Hodson, R. C. Smith, $r . S$ Metzger. F. Pennett, and D. P. Thayer of the los Alamos National Laboratory. The concepts discussed herein were developed during review of recording system options for the Los Alamos Artares laser facility.

\section{REFFRENCES}

1. D. $\because$ At twooo, R. L. Kaufman, G, L. Stradi ing, $r$. L. Medecki, R. A. Lerche, L. W. Coleman, F. L. Pitrce, S. W. Thomas, D. F. Camphell, J. Noonan, G. R. Tripp, R. J. Schnetz, and G, F. Phlllips, "Plcosecond $X$-Ray Measurements Froin $10 n$ eV to in keV." XIV International Conkress on Hiph speed Photography and Photonics (Noscow, USSR, Cot. $1980)$, and Lawrence Livermore Laboratory Feport UCRL-85043.

2. R. H. Day, P. Lee, F. P. Salomen, D, J. lapel, "Photoelectric Guant um Ffriciencles and Filter Window Absorption Coefficlents from in el to keV." to be published in Journal of Applied Physles," June, 1981.

3. R. H. Пay, "Photolontzation Negsurements for low Fnergy $X$-Fay Detector Applications," APS Conference on Low Fnerpy $X$-Ray riapnostics (Nonterey, CA), June, 1981.

4. G. Peck, Rev. Sci. Instr. 47 (1076), r. 840,

5. R. H. Day, P. Lee, F. P. Saloman, r. J. l'rpel, "X-Ray Diodes for Laser Fusion Plasma Tlagnostics," Los Alemos l'at.jonal Latoratory Report LA-7OLU-l'S (February, IOP1).

f. P. P. Lyons, R. H, ГAy, F. W, Lier, T, L, Fisrerry, "sub-keV Kany Celibration of FJestic scintlllators." Proceedinss of FRrA cymrosidT or $X$ - and Ciamme-Ray cources and Afrlications (Arn Artor, MI, 1076), CCNF-7(CK??, F. 70.

7. P. F. Lyons and J, Stevens, Nucl. Instr. end l'etr. 114 (9074) ???

P. P. P. Lyons, $i, P$, Hnckar, r. C, Crendall,. Chena, G. Tirseld, I'. R. l'urltut, iffF Trans, Pie. scl. MS-24 (1977) F. 177.

Q. P. P. l.yons, L. R. looney, J. CRle, R. r. Simmons A. Selk, P. Hopkins, L. Hocker, P. Melson, and $r$. Zaparino, "p'igh-ipere Photodetectors for plasmp. niapnostics." presented at los Alemos Conferener on Cptics (Aprll iop1), to he putlished ty ito soclety of Photo-Crticn) instrimentetion Fneincers and Los Al amos Mational lahoratory. erort L. $A-() R-81-10$ ?Q

10. F. T. Rockett, N. Printtorsky, r, Cisovenell!. "Radiation losses rrom lipk-i, ir ur InaerIrradiated Plerohalloons" los Mamos P'at lonel

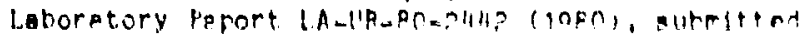
to Physles of FJulds.

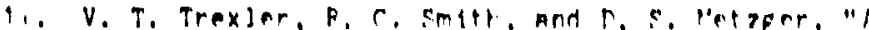

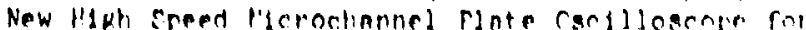
Fest Plasma liapnost IC " TFFF Internatione! Plasmn lliysica Conferenae (Pontrea), inen), iff

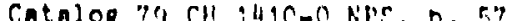

12. T. Hendrleks, "Fnualizer Handlionk," lemport $\mathrm{Ac}$

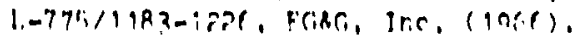

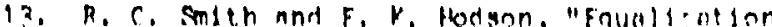
Concerta in the l-ic Gily Panpe," Les Mlamos Nat jonal lahoratoly, to pe putilistied.

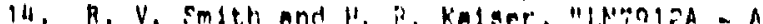
Prototype Trmelen Cloltlzar," lockteed kefort

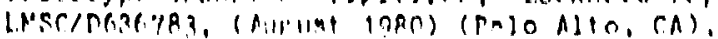

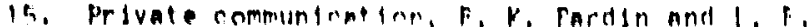
Chane (looklinad folo Alto Praenreh lal, (A) rad l'.

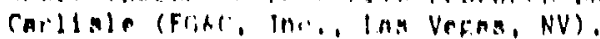

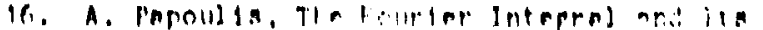

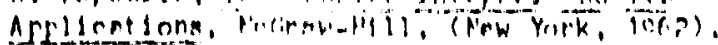

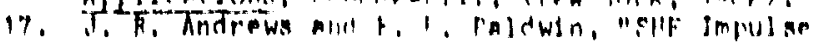

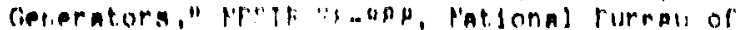

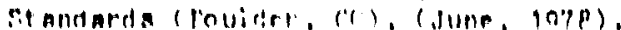


$1 \varepsilon$. J. R. Andrews. "Picosecond Pulse Generators Using Microminiature Mercury Switches." NPS IR 74-377. National Eureau of Standards (Eoulder, CO), Narch, 1974).

19. For example, Hewlett-Packard Model $1106 \mathrm{~B}$ Tunnel Diode Pulser

20. NBS Calibration Tes: No. B10268 (June, 1980) Eoulder, CO.

21. J. R. Andrews, N. S. Nahmen, "The Measurement of Pulse Transition Duration," Colloque int. Sur la Heasure en Telecommunications, URSI, Lannion, France), Oct. 1977, p. 15\%.

22. J. R. Andrews, IEEE Trans, Instr. Meas. IM-23 (1974) P. 46,

23. $\because \because$ Gans, J. R. Andrews, S. Riad, A. Cozannet, J. Debeau. "Application of an Automated Pulse
Measurement System to Teiecommunication

Measurements," Colloque Int. Sur la Measure en Telecommunications, URSI, (Lannion, France), nct. 1977 . P. 165 .

24. S. F. Caldwell and R. C. Smith, JFFE Incernational Plasma Physics Conference (Santa Fe, M', 1981) IF.FF Catalog No. $81 \mathrm{CH} 164 \mathrm{C}-2 \mathrm{~N}$ PS , F. 105.

25. R. C. Smith, F. K. Hodson, R. L. Carlson, "Nultigigahertz Peam Diagnostics for Laser Fusion." Presented at Los Alamos Conference on Cptics (April, 1981), to be published by the fociety of Fhoto-opticel Instrumentation Fngineers and Los Alamos National Laboratory Report LA-IIR-81-128?

26. F\&H Electronics, Inc.. Chester, N.Y.

27. E. K. Hodson, "Predictable Unrolding in the Time nomain," LOS Alamos National Laboratory feport $L A-3830(1067)$. 